\title{
Charting progress towards system-scale ecosystem service valuation in islands
}

THEMATIC SECTION

Humans and Island

Environments

\author{
KIRSTEN L.L. OLESON*1, SHANNA GRAFELD ${ }^{1}$, PIETER VAN \\ BEUKERING ${ }^{2}$, LUKE BRANDER ${ }^{2}$, PHILIP A.S. JAMES ${ }^{3}$ AND \\ ESTHER WOLFS \\ ${ }^{1}$ Natural Resources and Environmental Management, University of Hamai 'i Mānoa, 1910 East West Road, \\ Sherman 101, Honolulu, HI, USA, ${ }^{2}$ VU University Amsterdam, De Boelelaan 1087, $1081 \mathrm{HV}$ Amsterdam, The \\ Netherlands, ${ }^{3}$ Pacific Community (SPC), 95 Promenade Roger Laroque, BP D5, 98848 Nouméa, Nem Caledonia \\ and ${ }^{4}$ Sarphatistraat 370, 1018 GW, Amsterdam, The Netherlands \\ Date submitted: 2 July 2017; Date accepted: 2 March 2018; First published online 10 April 2018
}

\section{ABSTRACT}

Using islands as a model system, this paper seeks to understand how ecosystem service valuation (ESV) has and can move from a monetized, single-service paradigm to an integrated valuation paradigm, a participatory approach that represents a more diverse set of the values of nature, and beyond, to a more fully realized conception of the island social-ecological systems. A systematic literature review of 314 island ESV studies reveals developments in the design, implementation and adoption of ESV studies over time. We complement the review with three cases where this evolution is happening, thereby offering insights into successful means of translating ESV into information useful for island system-scale management, policy design and planning. Over the past 30 years, both the number of studies and the number of services addressed per study have steadily grown, and valuation methods have become more inclusive of multiple values. The cases reveal lessons for ESV practice. Insights are that ESV should increasingly: (i) recognize strong interconnections between ecosystems and between human and environmental systems; (ii) move towards more integrated valuation methods that better capture the diverse values of nature; and (iii) be based on an iterative process where knowledge and decision-support tools are co-created with decision-makers and stakeholders.

Keymords: ecosystem service valuation, environmental valuation, non-market valuation, systematic review, island sustainability

\section{INTRODUCTION}

The benefits that nature provides to humans - ecosystem goods and services or ecosystem services - underpin multiple dimensions of human well-being, including livelihoods, health

*Correspondence: Dr Kirsten L.L. Oleson email: koleson@hawaii. edu

Supplementary material can be found online at https://doi.org/ $10.1017 /$ S0376892918000140 and cultural heritage (Millennium Ecosystem Assessment 2005). The capacity of ecosystems to deliver services is diminishing globally, despite their fundamental role in supporting physical and cultural well-being (Helfenstein \& Kienast 2014). From an economic perspective, ecosystem services are seldom traded in markets and thus do not have readily observable prices that reflect their importance to society (Dixon 2008). This lack of market signal often leads to their omission in individual and collective decision-making, resulting in uninformed decisions that may unknowingly and inadvertently trade off important but poorly understood services for more obvious benefits. For instance, loss of coastal wetlands continues despite their critical importance for storm protection (Narayan et al. 2017).

One manner of conveying the importance of nature to society is through ecosystem service valuation (ESV). ESV quantifies the contribution to human well-being of environmental goods (tangible, material products) and services (intangible improvements in conditions) (Daily 1997), improving the transparency of any trade-offs inherent in decisions (Costanza et al. 2017). ESV can highlight the importance of natural capital to the economy, changes in ecosystem services flows and natural capital stocks, linkages between the economy and the environment and resilience of the economy to ecological change (Lawn 2003; Arrow et al. 2012; UNU-IHDP 2012).

ESV can also guide sustainability. At a minimum, sustainability requires ensuring that future generations have adequate access to resources to generate their well-being (Arrow et al. 2012). This implies that any reduction in ecosystem services is compensated by investment in natural or some other form of capital. Monetary ESV can identify the required reinvestment, and a toolbox of economic valuation methods exists to capture market and non-market services (Pascual et al. 2010).

Recent critiques, however, have pointed out that an economic paradigm poorly captures non-instrumental (i.e., intrinsic, relational) as well as non-individualistic values (Díaz et al. 2015; Kenter et al. 2015; Jacobs et al. 2016). Also, individuals are often poor judges of the contribution of nature to their wellbeing, so their individual willingness to pay (WTP) may be inaccurate (Norton et al. 1998). These omissions could imply that the level of reinvestment mandated 
by an economic ESV is insufficient to ensure non-declining future welfare. Moreover, Arrow et al.'s (2012) minimal economic criterion of sustainability as a non-declining, welfare-generating capital stock neglects critical determinants of well-being, namely equity, agency and resilience (Díaz et al. 2015). To guide societally meaningful sustainability, ESV will thus need to embrace broad drivers of welfare distribution, decision-making power and ecosystem stability (Hicks et al. 2016).

A new valuation paradigm argues that integrated approaches may improve the ability of ESV to guide sustainability (Pascual et al. 2010; Díaz et al. 2015; Kenter et al. 2015; Jacobs et al. 2016). This argument contends that combining socio-cultural, ecological and economic valuation tools in a participatory process involving stakeholders and decision-makers will be more fair and inclusive of the pluralistic values of nature. Furthermore, a social-ecological systems (SESs) approach to ESV may better reflect ecological processes generating ecosystem services, as well as human use of and influence on the system (Bagstad et al. 2013; Costanza et al. 2017). Computer models simulating ecosystem dynamics can greatly enhance the ability to manage a SES using a resilience approach (Walker et al. 2004; Folke 2006), which explicitly recognizes the dynamic ecological connections between biophysical systems (Stoms et al. 2005; Alvarez-Romero et al. 2011), the complex linkages between humans and their environment (Liu et al. 2007) and feedbacks that may result in nonlinear system behaviour (Folke 2006).

Adopting an integrated valuation paradigm - a participatory approach that represents a more diverse set of the values of nature - and beyond, to a more fully realized conception of an SES may improve the accuracy, robustness and perceived legitimacy of ESV (Jacobs et al. 2016; Costanza et al. 2017). This in turn may enhance the uptake of ESV principles and results in management and policy (Ruckelshaus et al. 2008; Laurans et al. 2013b; Waite et al. 2015). A shift towards a more integrated valuation paradigm is particularly evident in the literature focused on island systems.

Islands are microcosms of the world. Perhaps more than any other system, islands tangibly exhibit the intimate interlinkages between humans and the environment (Chertow et al. 2013). Environmental change can have direct and rapid implications for nature and island residents, who typically rely heavily on natural resources for their well-being (Pachauri \& Reisinger 2007; Hong 2013). Though threatened, island SESs are resilient, with well-adapted natural diversity and socialcultural institutions (MacArthur \& Wilson 1967; Hau'ofa 1994; Berkes et al. 2000; Gough et al. 2010). Other systems share these characteristics, but islands' clear boundaries and relative isolation make them excellent study systems. Islands offer an opportunity to demonstrate and test how valuation approaches can inform policy and guide sustainability. Here, we follow a well-established tradition in ecology and beyond (MacArthur \& Wilson 1967; Chertow et al. 2013) and use studies on islands to clarify processes, dependencies and interactions, assuming these results will illuminate our perspectives in a diversity of other systems.

Using islands as model systems, the goals of this paper are twofold: (1) to understand how island-based ESV can move from a monetized, single-service paradigm to an integrated valuation paradigm, a participatory approach that represents a more diverse set of the values of nature, and beyond, to a more fully realized conception of the island SES; and (2) to explore how different forms of ESV have successfully or unsuccessfully informed island system-scale management, policy and broad sustainability efforts.

We conduct a systematic literature review analysing the trends within ESV on islands, which point at the changes in the design, implementation and adoption of ESV studies over time. Three cases where this development is happening illustrate this evolution and the practical uptake of ESV information in island system-scale management, policy design and planning. We then discuss ways to increase ESV's robustness, inclusiveness and usefulness.

The paper is structured as follows. We describe the methods for the literature review and case studies. The results of the review precede in-depth narratives of the three cases for Hawai'i, Bonaire and Fiji. Our discussion then presents a number of key insights from our analysis.

\section{METHODS}

A thorough literature search compiled a database of ESV studies conducted on islands (oceanic islands, defined as noncontinental land masses that were completely surrounded by water and permanently inhabited by humans) across multiple ecosystem types and services (Supplementary Table $\mathrm{S} 1$; available online). Six different scientific repositories were used: National Ocean Economics Program, Gulf of Mexico Ecosystem Services Valuation Database, Google Scholar, Web of Science, Science Direct and the Ecosystem Services Valuation Database. Several different keywords were used to search for relevant studies: ecosystem services; valuation; total economic value; Caribbean; Pacific; coral; mangrove; seagrass; forest; and cultural ecosystem services. Information from previous reviews was also extracted (Brander et al. 2006, 2007, 2012; Hussain et al. 2011; Laurans et al. 2013a). Studies were inputted if they provided a quantitative or qualitative valuation of at least one provisioning, regulating, cultural or supporting ecosystem service. Studies did not necessarily need to use the term 'ecosystem service', but had to value (biophysically, monetarily or qualitatively) at least one benefit of nature. Details recorded include location, ecosystem service(s) valued, methods used and whether the study took a spatial and/or participatory approach to valuation. Each service within a single study was counted (e.g., a study valuing sediment retention, biodiversity and food production was recorded as $1+1+1=3$ total ecosystem services). 'Spatial' required geolocation of the service, while 'participatory' required some form of meaningful feedback between stakeholders whose values were being assessed and 
the researchers, be it in study design, choice of methods, elicitation procedure or discussion of results.

To complement the literature analysis and demonstrate how some of the overall trends have played out in reality, we focus on three case studies (Hawai'i, Bonaire and Fiji) where the authors have substantial experience and where ESV has been used in distinct, illustrative ways. We sought out cases to: (i) ground the trends observed in the literature; (ii) explore the use of integrated approaches to valuation; and (iii) examine whether and how concepts from ESV were taken up by policy-makers (using McKenzie et al.'s (2014) conceptual (i.e., knowledge broadens understanding and shapes values), strategic (i.e., supporting specific policy or justifying beliefs/values) and instrumental (i.e., direct use in decisions) use modes, which correspond to Laurans et al.'s (2013b) informative, decisive and technical use), with particular attention being paid to incorporating ESV principles as part of broader SES thinking applied to islandscale sustainability efforts.

The three cases geographically span the tropics, and each displays characteristics typical of tropical islands, namely scarce resources being taxed by a tourism-based economy, population growth and land use change. All three sites have marine areas that are far larger than their land areas and strong cultural ties to the ocean. The cases provide some contrast, with Hawai' $i$ and Bonaire being part of the USA and the EU, respectively, with higher-income economies dominated by tourism, while Fiji is an independent, middleincome, developing island nation whose economy still includes substantial subsistence agricultural and fisheries sectors. Hawai' $i$ and Bonaire have long histories of ESV, while Fiji's ESV literature is more recent.

The Hawaiian archipelago, the northernmost island group of Polynesia, stretches $2400 \mathrm{~km}$ in the middle of the Pacific Ocean. The eight main Hawaiian Islands have a total land area of $16600 \mathrm{~km}^{2}$, while the state's total area (including ocean) is over $28000 \mathrm{~km}^{2}$. The seven inhabited islands host 1.4 million people, most of whom (just under one million) live on the island of O'ahu (State of Hawai'i DBEDT 2016). Hawai' $i$ attracts over nine million tourists a year, constituting about $16 \%$ of the state total gross domestic product (GDP; $\$ 87.3$ billion) (State of Hawai'i DBEDT 2016, 2017).

Bonaire, one of six islands of The Netherlands Antilles in the Caribbean Archipelago, is located $80 \mathrm{~km}$ north of Venezuela. The surface of Bonaire is $294 \mathrm{~km}^{2}$ and measures $38 \mathrm{~km}$ from north to south and a maximum of $11 \mathrm{~km}$ wide from east to west. The 2010 census estimated the population as 15666 people. Bonaire's economy (US\$415 million in 2015; Statline 2017) is supported by its popularity as a dive destination, drawing 270000 visitors per year, who contributed 16\% of total GDP in 2012 (Schep et al. 2012; CBS 2015).

Fiji, an island republic in Melanesia, has an exclusive economic zone of $1290000 \mathrm{~km}^{2}, 60$ times its land mass (Gonzales et al. 2015). Tourism makes up 20\% of GDP (US\$800 million) (Fiji Bureau of Statistics 2017). Travel and
Table 1 Number of value estimates per ecosystem service category.

\begin{tabular}{llr}
\hline \hline Service & Category & Count \\
\hline Provisioning total & & 142 \\
Fisheries - commercial/subsistence & Provisioning & 116 \\
Timber & Provisioning & 11 \\
Agriculture/aquaculture & Provisioning & 10 \\
Other & Provisioning & 5 \\
Cultural total & & 644 \\
Tourism and recreation & Cultural & 400 \\
Fisheries - recreational & Cultural & 59 \\
Research/education & Cultural & 38 \\
Amenity & Cultural & 19 \\
Other cultural & Cultural & 128 \\
Regulating total & & 164 \\
Coastal protection & Regulating & 73 \\
Water quality & Regulating & 47 \\
Carbon sequestration & Regulating & 30 \\
Water flow & Regulating & 11 \\
Other regulating & Regulating & 3 \\
Supporting total & & 62 \\
Biodiversity & Supporting & 62 \\
All categories total & All & 1012 \\
\hline \hline
\end{tabular}

tourism accounted for $12.3 \%$ of the total employment (World Travel \& Tourism Council 2015), with visitor numbers in 2014 reaching 780000 people, over $80 \%$ of the permanent population of Fiji (Secretariat of the Pacific Community 2017a). Natural resources directly support another 14\% of GDP through agriculture, forestry, fishing and mining (Fiji Bureau of Statistics 2017) and 16\% of households rely on agriculture and forestry for their incomes (Secretariat of the Pacific Community 2017b).

\section{RESULTS}

\section{Database review}

We identified 314 island-based ESV studies (Supplementary Information). These studies used a wide variety of methods ranging from traditional economic methods based upon WTP to novel social science discourse-based methods to value 1012 particular ecosystem services (N.B., each service valued within a given study was counted as a single service). The earliest study, which valued recreation on $\mathrm{O}^{\prime}$ ahu, Hawai' $i$, was conducted in 1973, after which there was a significant hiatus in the literature until 1988. Focusing on the past 30 years (19882017), the total number of valuations has steadily increased (Fig. 1(a)) and the number of ecosystem services assessed in each ESV study has increased over time (Fig. 1(b)), resulting in a rapid growth in the number of ecosystem services valued in islands (Figure 1(c)).

Valuations have focused on an array of ecosystem services spanning land and sea (Table 1). By far, cultural services were most commonly valued, with tourism (i.e., diving, snorkelling, recreation) value dominating. Tourism has remained a frequently valued ecosystem service, though other services 

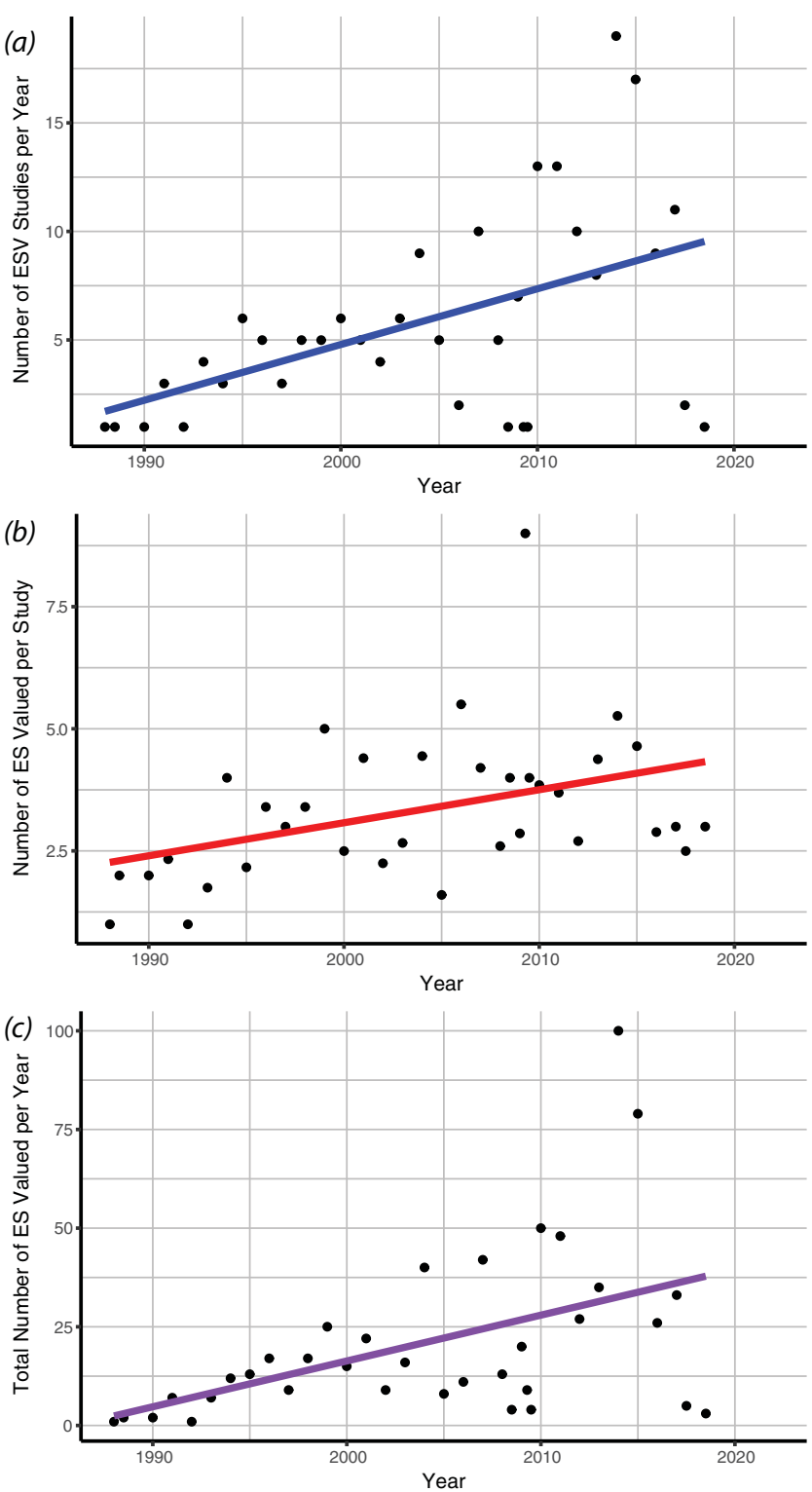

Figure 1 Ecosystem service valuation (ESV) studies for islands, 1985-2017. (a) Number of studies per year $(+0.26$ studies/year; $\left.r^{2}=0.25 ; p=0.0022\right)$. (b) Number of services per study $(+0.07$ services/(study $\times$ year); $\left.r^{2}=0.16 ; p=0.016\right)$. (c) Total number of services valued per year $\left(+1.16\right.$ services $/$ year; $\left.r^{2}=0.23 ; p=0.004\right)$.

have become increasingly common, particularly other facets of cultural ecosystem services and regulating services (Fig. 2).

The global coverage of these studies (Fig. 3) shows geographic bias towards the USA, particularly the Hawaiian archipelago. Islands in Southeast Asia and the Caribbean received substantial attention in early years, while the Pacific and the Caribbean have had the largest proportion of studies more recently.

As the total number of studies has increased over time, there has been a notable acceleration in methods that allow for the consideration of ESV beyond those with functioning markets. Contingent valuation in particular has
Table 2 Count of specific valuation methods and approaches used in ecosystem service valuation.

\begin{tabular}{llc}
\hline \hline & Method & Count \\
\hline Consumer behaviour & Contingent valuation & 129 \\
& Choice experiment & 83 \\
& Travel cost & 41 \\
& Hedonic pricing & 13 \\
Production linkages & Gross revenue & 105 \\
& Net factor income & 69 \\
& Production function & 38 \\
& Market price & 2 \\
Cost-based & Replacement cost & 31 \\
& Avoided cost & 11 \\
Value transfer & Value transfer & 88 \\
Biophysical & Geospatial mapping & 24 \\
& Biophysical modelling & 19 \\
Qualitative & Surveys & 67 \\
& Descriptive & 32 \\
\hline Approach & & Count \\
\hline Participatory & & 33 \\
Spatial & & 69 \\
Mixed (market and non-market) valuation &
\end{tabular}

been frequently employed, although choice experiments seem to be gaining favour as a more comprehensive method to measure use and non-use values (Table 2). In recent years, more studies have mixed market and non-market methods to monetize ecosystem services, some connected to a biophysical model. With improved online survey opportunities, more advanced spatial tools and increased availability of social media data, there is an emerging trend in the use of social surveys, mapping and other methods that allow for more inclusive, qualitative valuations (Fig. 4 and Supplementary Fig. S1).

\section{Case studies}

\section{Hamai' $i$}

As the location with the most island ESVs in our database, Hawai' $i$ offers a robust case to investigate trends in ESV practice. Hawaiian ESVs have expanded in scope and methods, including innovations to capture indigenous cultural values. Studies done in partnership with management agencies featuring interconnected biophysical-economic models have had particularly strong policy impact, while the overall body of ESV studies done in Hawai ' $i$ has flavoured state sustainability discourse and indicators.

Evolution of ESVs in Hamai'i. Similar to the valuation literature review, many studies in Hawai' $i$ have highlighted the critical role of the ocean for Hawaiian quality of life. The economically important tourism sector motivated the earliest study in the island valuation database and a string of recreational valuation studies thereafter. Studies of provisioning marine services have highlighted the importance of fisheries to the economy and society, as well as the impacts of 
Figure 2 Number of value estimates in each ecosystem service category over time. Tourism was pulled from 'cultural' and included as its own category.
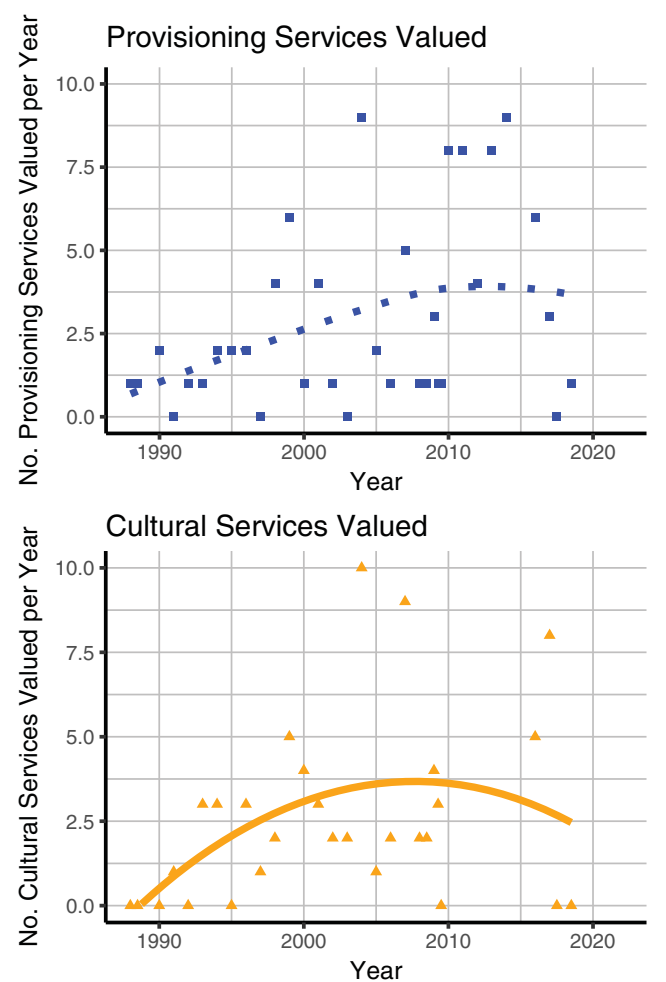
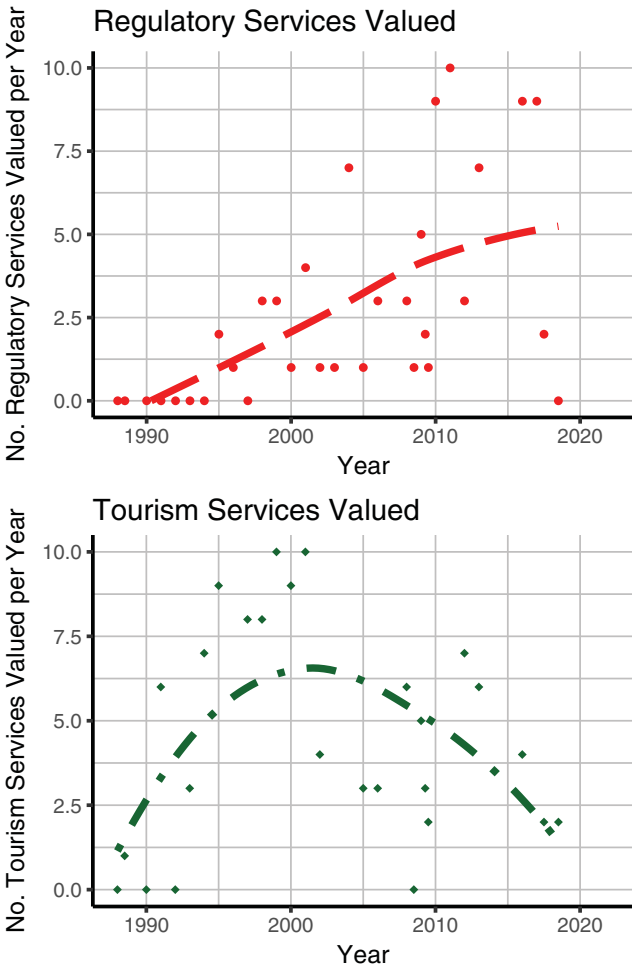

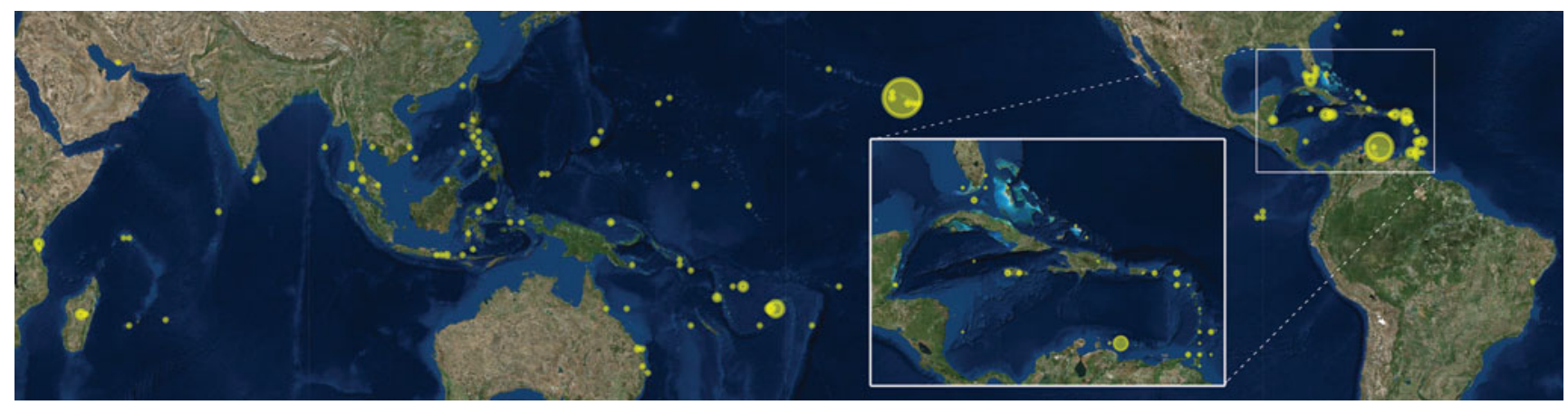

Figure 3 Global distribution of ecosystem service valuation studies. Size of the dot reflects the number of ecosystem service valuation studies in each location.

management and policy. While the ocean certainly dominates, Hawaiian ESV is distinguished from the overall island literature database by its attention to terrestrial ecosystems. A particular interest is the impact of invasive species on waterregulating and -provisioning services. Representing the new frontier in valuation methods, one study tackled relational value for people with deep generational and cultural ties to land (Pascua et al. 2017), and another the non-material values from cultural services (Gould et al. 2015).

Similar to the overall trend, studies seem to have moved from a single-ecosystem service focus to multiple services employing multiple valuation methods. We also see evidence of systems approaches to ecosystem services modelling in Hawai $i$, ranging from studies using spatial biophysical modelling with production functions (Goldstein et al. 2012; Wada et al. 2017) to more complex models that capture economic and ecological feedbacks (van Beukering \& Cesar 2004).

Practical uptake of ESV. Several ESV studies have influenced management practices and state policy. Some commonalities amongst these impactful valuation studies are their integration of biophysical modelling with economic valuation, resulting from strong collaborations between natural scientists and economists and partnerships between academics and resource management agencies. Cesar and van Beukering's (2004) ecological-economic coral reef model, funded by the National Oceanic and Atmospheric Administration, helped set administrative penalties for damage to coral reefs and live rock (State of Hawai'i 2008). Forests' value for water supply was the subject of multiple ESV studies that linked biophysical (land cover/land use, groundwater) and economic models to 
Figure 4 Proportion of ecosystem service valuation studies by method (mixed, inclusive only, biophysical only, non-market only or market only). A mixed approach represents at least two methods within the same study. 'Inclusive' only refers to descriptive, qualitative methods and studies that used structured or semi-structured surveys to elicit values. 'Biophysical' only used geographic information system or biophysical models.

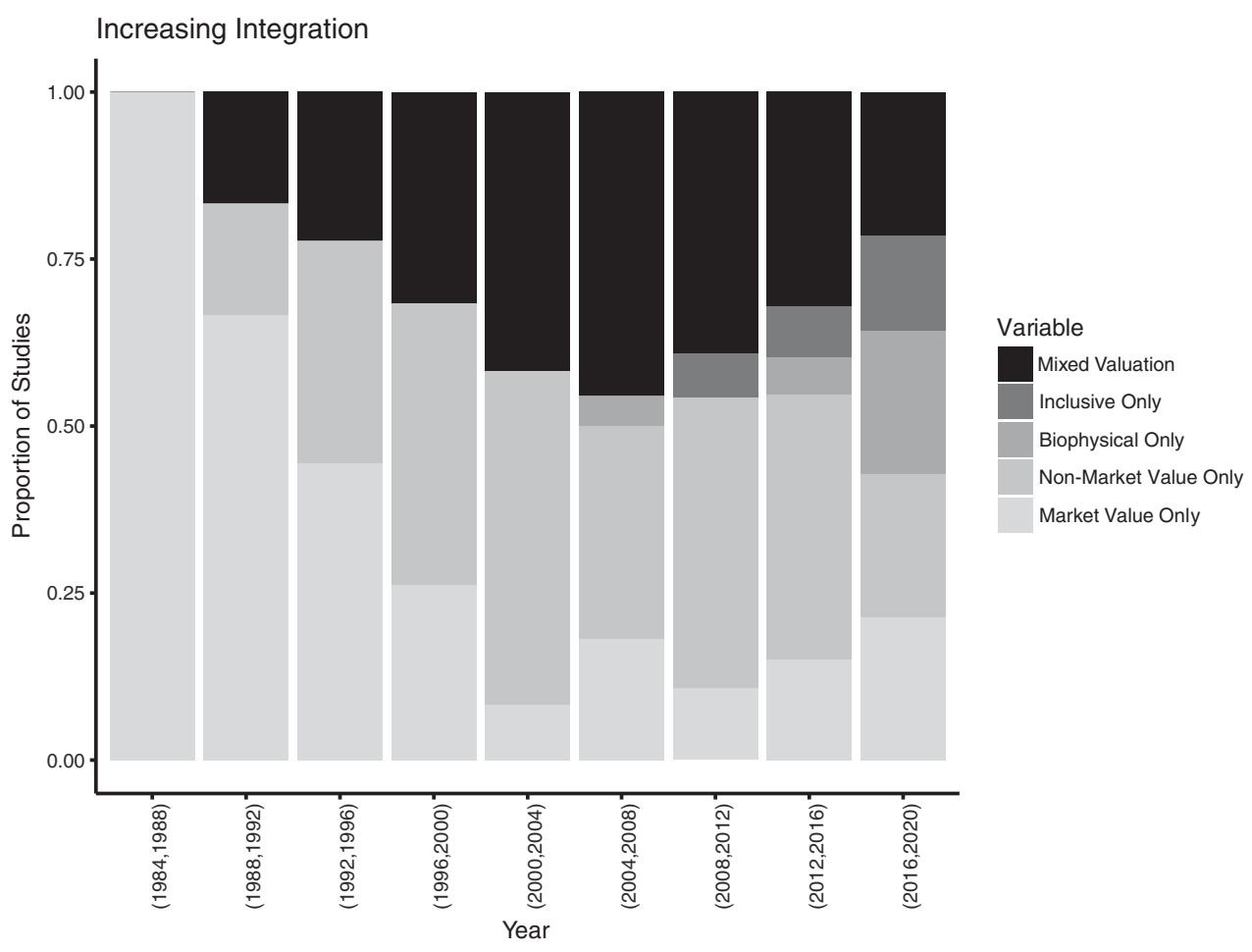

ultimately inform freshwater management and policy (State of Hawai'i DLNR 2010, 2011; Hawai' $i$ Fresh Water Initiative 2016). This work led to explicit calls for investment in the protection of natural capital and full-value pricing of water and increased budgets for invasive species control.

Perhaps the most profound influence of ESV has been conceptually highlighting how nature nourishes the people and economy of Hawai' $i$. The importance of the environment for the economy and human well-being is embedded in a state effort to measure 'progress'. Hawai' $i$ has joined a small cohort of other states in an effort to replace the leading economic indicator used to evaluate economic growth, the GDP, with an alternative, the genuine progress indicator (GPI) (Lawn 2003). GPI uses ESV to adjust GDP for environmental changes. While not perfect for island settings and in dire need of localized valuation studies, GPI provides a framework to synthesize and report on trends across Hawai'i's broad sustainability goals (Ostergaard-Klem \& Oleson 2014). A bill calling for the state to produce GPI was recently introduced in the state legislature.

Looking formard. The 'Sustainable Hawai'i Initiative' commits to achieving $100 \%$ renewable electricity, doubling local food production, implementing a biosecurity plan, protecting $30 \%$ of priority watersheds and effectively managing $30 \%$ of nearshore ocean waters by 2030 . Additional ESV studies could help advance this agenda. Evaluating the ecosystem service benefits of alternative watershed and marine protection plans could help identify cost-effective spatial arrangements of integrated land-sea conservation actions that balance benefits for multiple stakeholders while minimizing contentious trade-offs. Fully accounting for the ecosystem services delivered by agricultural plans to double local food production could highlight synergies amongst and trade-offs between objectives (i.e., agricultural futures that achieve gains in local food, sediment retention and cultural practices) versus those that might be environmentally harmful and conflict with cultural traditions and sense of place. Quantifying the costs and benefits of biodiversity loss and invasive species could help justify and optimize biosecurity and conservation initiatives. Finally, inclusive valuation of Hawai'i's precious water resources could reinforce indigenous interests and rights as well as the broader public's interest (Martin et al. 1996). All of these will require robust biophysical models, participatory valuation processes open to diverse worldviews and value sets and decision-support tools to objectively assess the trade-offs between multiple, largely incommensurate value sets.

\section{Bonaire}

The evolution of ESV on the island of Bonaire illustrates the trends identified in the literature review. Over time, valuation studies in Bonaire incorporated an increasing number of ecosystem services, moved from solely using valuation techniques to more comprehensive and inclusive methods and changed their target audience from specific users to island-wide stakeholders. Each phase in the ESV history on Bonaire also marks explicit policy impacts.

First evidence of economic valuation impact (1993-2010). The Bonaire National Marine Park (BNMP) surrounds the entire island. Established in 1979, BNMP was a 'paper park' for many years as funding was plagued by instability (Spergel 
2005). In 1991, the management of the BNMP was revitalized with government funding, with the premise that the park should become self-financed, hinting at the introduction of user fees. Given the controversy surrounding user fees, a contingent valuation survey was conducted to infer visitors' WTP for user fees for the BNMP. Overall WTP exceeded the relatively modest US $\$ 10$ fee that was proposed at that time (Dixon et al. 1993, 2000).

Supported by Dixon et al.'s ESV study, user fees were introduced in 1992, leading to $90 \%$ coverage of financial needs by 2000 (De Meyer \& MacRae 2006). Several years later, again supported by two ESV studies (Parsons \& Thur 2008; Thur 2010), a diversified fee system replaced the original user fee system in Bonaire, setting specific fee levels for different users (Kushner et al. 2012). The Bonaire experience in the region demonstrates that self-financing is a viable option for many of the region's protected areas that attract large numbers of visitors. Several protected areas in The Netherlands Antilles now have effective revenue generation strategies, and as a result are among the best managed in the region. BNMP is recognized by the International Coral Reef Initiative as 'one of the best-managed marine parks in the world' (STINAPA 2008).

Second-mave ESV studies (2010-2013). Driven by several international conventions and treaties aiming to protect biodiversity, The Netherlands was encouraged to develop more effective environmental policies and regulations. In 2011, this obligation led The Netherlands' government to initiate 'The Economics of Ecosystems and Biodiversity' (TEEB) study to create an understanding of the value of ecosystem services in the Caribbean Netherlands, including Bonaire. The TEEB study aimed to increase awareness about the importance of natural capital for society and to support more sustainable decision-making. An extensive ESV study resulted in the mapping and monetization of ten ecosystem services, including fisheries, cultural values, tourism, non-use values, carbon and coastal protection; the cumulative sum of all ten was the total economic value of ecosystem services on Bonaire. The TEEB Bonaire study is internationally recognized for successfully bridging the science-policy gap through raising awareness, supporting policies and developing mechanisms for sustainable financing (Waite et al. 2015; McFarland \& Gerdes 2016).

The TEEB Bonaire study has directly generated financial resources for nature conservation on Bonaire. Insight into the discrepancy between the willingness of Dutch mainland citizens to pay for nature conservation on Bonaire in the Caribbean Netherlands and the lack of actual funding were used by the Ministry of Economic Affairs to secure US $\$ 5.2$ million investment for nature conservation on Bonaire. Moreover, encouraged by the high WTP of beneficiaries of crucial ecosystem services on Bonaire, World Wildlife Fund for Nature - Netherlands allocated a substantial budget for nature conservation on Bonaire (Sewell 2015).
Third phase moving tomards holistic approaches (2013 to present). The TEEB study was discussed in the Dutch Parliament and was actively used by the State Secretary of Economic Affairs to showcase the important link between nature and economic prosperity. Furthermore, through ample publicity in the local media and a documentary, the study raised awareness about the sustainability of the economy of Bonaire. Residents are now better aware of the importance of nature for their own well-being and the disastrous effect of goats on the terrestrial ecosystems and coral reefs. The awareness-raising influence stretches beyond Bonaire. During the International Coral Reef Initiative (ICRI) General Meeting 28, the TEEB study inspired regional managers to organize a seminar for Caribbean practitioners on Bonaire in 2014. The Caribbean Marine Protected Area Management disseminated the results of the TEEB study to British, French and Dutch Caribbean marine protected area (MPA) managers, and the International Union for Conservation of Nature (IUCN) International and Blue Solutions present the Bonaire case as best practice. The TEEB study was also used for educational purposes in handbooks (Mumby et al. 2014) and in classrooms (e.g., Texas A\&M University).

Moving forward, a policy monitoring instrument for the local government of Bonaire is currently being developed, with the aim to measure the island's progress towards a sustainable economy as spelled out in the Integrated Multi-Year Plan of Bonaire (Openbaar Lichaam Bonaire 2015). Moreover, using the information collected in the TEEB study, an ecologicaleconomic input-output model was developed that aims to create insight into the importance of natural capital for the local economy in terms of GDP and employment (Koks et al. 2015).

\section{Fiji}

Fiji is emblematic of many other small, developing islands in the Pacific, where ESV is a relatively recent phenomenon with enormous potential to guide policy. Reflecting the scope of other studies in the literature, ESVs done in Fiji encompass a broad array of values, reflecting the island's high dependence on the environment for its tourism economy, as well as people's livelihood functions, health and well-being (Rao et al. 2013; Gonzales et al. 2015).

Evolution of ESV. Primary research-based ecosystem valuation studies are scarce in Fiji and are often in the grey literature. Those that do exist largely originate from the mid-2000s onwards and reflect the multi-system and -service approaches of other studies in that period. The vast majority of Fijian ESV concerns the coral reef or marine systems, an indication of how vital these systems are to people's livelihoods and the Fijian economy. Very few terrestrial ESV studies exist. Data scarcity drives Fiji's reliance on the transfer pricing method. Many studies also have some form of descriptive valuation. Studies that used contingent valuation methods to elicit bequest value showed that cultural values are significant drivers of local preferences associated with traditional fishing 
grounds (iqoliqolis). O'Garra (2012) and Pascal and Seidel (2013) nonetheless found that tourism value was still likely to dominate other values.

Practical uptake of ESV. Valuation of non-market impacts has influenced policy decisions in Fiji. For instance, an estimate of damage costs on individuals' health and community cohesion was crucial in the ministerial decision to ban the practice of using air tanks to deep dive for sea cucumber (TabunakawaiVakalalabure et al. 2017).

ESV has also influenced the Fiji National Biodiversity Strategy and Action Plan, which seeks ' $[\mathrm{t}] \mathrm{o}$ conserve and sustainably use Fiji's terrestrial, freshwater and marine biodiversity, and to maintain the ecological processes and systems which are the foundation of national and local development' (Fiji 2007). Citing Sisto's (1999) findings valuing ecosystem services at $40 \%$ of the country's GDP, the Plan emphasizes that 'in order to compete for the attention of government decision makers in today's world, policies regarding biological diversity first need to demonstrate in economic terms the value of biological resources to a country's social and economic development.'

One focus of conservation effort has been on Fiji's coastal and marine areas, crucial sources of both local and global ecosystem services. In 2005, the Government of Fiji committed to protect $30 \%$ of its seas as MPAs by 2020 (IUCN 2016), and in 2017, Fiji hosted the UN Ocean Conference in New York, where they pledged voluntary commitments towards protection and sustainable management of marine ecosystems (Mangubhai 2017). Two important themes emerged within these commitments: first, the Government of Fiji recognized that ecosystem connectivity is a key element and the vital role of ridge-to-reef coastal management (Fiji DOE 2017; Mangubhai 2017); and second, the commitments explicitly cited the monetary economic contribution of fisheries and tourism for the Vatu-i-Ra Seascape and Great Sea Reef as justification for protection.

While the central government recognizes the systems connectivity and economic value of key sectors, much of Fiji's commitment to ecosystem sustainability is achieved through local management. Provincial-scale integrated coastal management plans have not used ESV to inform trade-offs and justify conservation measures (J.-B. Marre, personal communication 2017), but the value of ecosystem services at the local scale has attracted funding and stimulated national policy support. For example, van Beukering and Lea (2013) documented how ecosystem services embedded in three elements of poverty (opportunity, empowerment and security) improved more within Fiji's locally managed marine areas (FLMMAs) compared to similar villages outside. They showed that local popularity of the concept of LMMAs was entirely based on the multitude of benefits for local communities, including food, livelihoods, spiritual and cultural values and social cohesion. Perceived value of LMMAs has fomented expansion of the FLMMA network to some 250 areas covering more than $25 \%$ of Fiji's inshore area (United Nations Development Programme 2012).

Looking formard. As interest expands across the Pacific islands to exploit vast seabed mineral deposits, ESV could play a pivotal role. The world's first deep sea mining project will begin in early 2019 in Papua New Guinea after the country issued the first lease for deep sea mining. A study estimating that the project will deliver US $\$ 83.3$ million in benefits neglected to include the costs of the mining on ecosystem services and other affected industries such as tourism and tuna (Cardno 2016). Accurately estimating these externalities is currently stymied by data scarcity (Gonzales et al. 2015), suggesting a need for ESV studies that could provide thorough full-cost accounting of all impacts, including those on cultural and more intangible services. Given that mining could have widespread impacts across the SESs, from tuna to tourism, more systematic thinking should be employed to ensure tradeoffs are adequately assessed.

\section{DISCUSSION}

\section{Insights}

Our review of the ESV literature in islands and in-depth analysis of three cases offers some specific insights that can help make ESV more robust by better reflecting pluralistic values and the complex and dynamic nature of island SESs. These insights address and build on an ongoing discussion, spurred by recent studies questioning the utility of ESV to guide coastal management (Lal 2004; Pascal et al. 2012; Marre et al. 2016) and analyses of global experience suggesting specific contextual requirements and enabling conditions related to study design, stakeholder engagement, communications and governance that make it more likely that ecosystem service knowledge and valuation will be used in decisions (Nunes 2014; Ruckelshaus et al. 2015; Waite et al. 2015; Salcone et al. 2016). Our methodological and procedural suggestions derived from our analysis of island $\mathrm{ESV}$ are aimed at making ESV more accurate, robust and useful for policy analysis and sustainability efforts.

Insight 1: ESV should reflect SES interconnectedness. Social and natural systems are strongly connected in islands. Ecosystem services result from complex ecological interactions, human activity affects ecosystems' ability to produce services and human demand for ecosystem services depends on context (Nelson et al. 2006; Carpenter et al. 2009; Villamagna et al. 2013). Given that island systems will likely have feedbacks where changes in one system will prompt shifts in another, ESV should be based on models that connect systems at a scale relevant to the decision at hand (Daily et al. 2009; Nelson et al. 2009).

A first step towards better interconnectedness is robust ecological models that are able to predict ecological responses relevant to people (EPA 2009; Yee et al. 2015). We saw examples of this in the Hawai' $i$ case study, where groundwater 
recharge models illuminated impacts of land cover and invasive species within specific watersheds. In Fiji, recent work investigates the impacts of land-based activities on reefs (Klein et al. 2014; Brown et al. 2017). These ecological models should be based on a sound understanding of the ecology underpinning systems, including carrying capacity and thresholds (Kremen 2005), and land-sea interactions (Reuter et al. 2016). Ecological tipping points within Hawai'i's nearshore environment were the subject of a recent research endeavour (oceantippingpoints.org/Hawaii), and operationalization of the findings is a future challenge for the system's modellers.

The second step towards better interconnectedness is establishing ecological-economic relationships (production functions) to translate ecological conditions into potential service delivery (EPA 2009; Yee et al. 2014). Notably, these are far more developed for provisioning and regulating services than for cultural services, which are less defined in the literature and can be place specific (Chan et al. 2012b; Fish et al. 2016).

Most ecosystem service assessments stop at the second step; however, a third step is required to connect the assessment to valuation: methods to quantify demand in order to pinpoint the final ecosystem services that actually benefit people (de Groot et al. 2002; Boyd \& Banzhaf 2007; Villamagna et al. 2013). One approach is spatial modelling of demand (DeFries et al. 2004; Burkhard et al. 2012; Bagstad et al. 2014). We could find no examples in our island database that explicitly quantified actual demand.

A more robust approach to ecosystem service modelling involves integrating the ecological and social systems dynamically to capture interactions and feedbacks (Berkes \& Folke 1998; Alberti et al. 2011). Social-ecological feedbacks include human activities that may affect the ecosystem's capacity to generate services and internal factors that affect demand for services (Villamagna et al. 2013). In Hawai' $i$, van Beukering and Cesar (2004) used a dynamic ecologicaleconomic model to simulate how tourism affected the state of the reef in order to assess the costs and benefits of alternative management strategies. Dynamic systems models can be used to assess resilience to risks from natural disasters, climate change, habitat loss, invasive species, human activities and other imminent threats to ecosystem services, public health and local economies (Gunderson 2001; Hernández-Delgado 2015).

A solid ecological-economic basis for ESV with clear presentation of methods, assumptions, limitations and uncertainties will improve confidence in and legitimacy of service delivery assessments and associated valuations (EPA 2009; Seppelt et al. 2011; Waite et al. 2015). These would address the key needs of decision-makers who must assess whether analyses are adequately accurate to guide action (Ruckelshaus et al. 2015). For islands, this suggests a broader research agenda of collaborating with natural and social scientists to develop robust, system-scale land-sea ecologicaleconomic models.
Insight 2: develop and use alternative valuation approaches to capture multiple types of value. One notable feature of the ESV research conducted in islands is that a large portion of studies focus on recreation, and more specifically tourism. This bias is likely due to the fact that valuation of tourism is easier relative to other ecosystem services. Tourism undoubtedly constitutes an important ecosystem service in many island systems and can be particularly influential in affecting decisions. The motivation for tourism-focused studies could be to set user fees for parks, seek favourable policies for the tourism sector or convince policy-makers to sustainably manage nature. However, a focus on tourism could obscure other cultural services provided by island ecosystems that give them a unique sense of place or are particularly important for local people. In certain scenarios, managing for tourism ecosystem services could even result in trade-offs of other services (Davenport \& Davenport 2006; Bennett et al. 2009). Moreover, counting only the benefits and not the costs of tourism (e.g., waste management, water use and resource damage) is likely to overestimate tourism's net benefits and exacerbate inequities (David et al. 2007), speaking to the need to include all nonmarket impacts.

The recent diversification of ecosystem services and values included in ESV studies within our review indicates recognition of the importance of ecosystem services beyond tourism. It also likely reflects different motivations for ESV studies. Multi-service and -value ESVs may intend to raise general awareness of nature's broad importance to the economy, people and culture (conceptual use) and to leverage change in economic development policies (strategic use).

While the number of other cultural services captured in island ESVs has increased in recent years, many are still underrepresented (i.e., science/education, indigenous/heritage, spiritual and aesthetic/amenity). This speaks to the difficulty of quantifying cultural ecosystem services connected to deep-seated ethical and social/shared values (Chan et al. 2012a; Kenter et al. 2015). Indeed, Hawaiian managers expressed deep unease with the idea of quantifying or, worse, monetizing cultural services (Bremer et al. 2015), perhaps reflecting the relational values people have with nature (Chan et al. 2016), such as in defining ways of life, cultural identity and social cohesion (Pascua et al. 2017). This leaves ESV researchers with a challenge - cultural services beyond recreation and tourism are very important for resource managers (Pleasant $e t$ al. 2014) and highly valuable to society (Russell et al. 2013), particularly to native peoples. Omitting cultural services from environmental assessments and decisions may result in unintended trade-offs (Satz et al. 2013), yet their quantification and monetization can be culturally inappropriate, and alternative valuation methods that get at these values are nascent, time-consuming and expensive (Jacobs et al. 2016).

The ESV community, through deeper collaboration with other social scientists, needs to continue broadening the scope of non-monetary valuation methods in order to capture 
the full range of values people hold for nature. A rich literature has emerged, developing social science-informed valuation methods (e.g., Wilson \& Howarth 2002; Van Berkel \& Verburg 2014; Kenter et al. 2016; Mavrommati et al. 2017). Some approaches depart altogether from the economicdominated perspective towards one that acknowledges diverse worldviews, adopting a wholly different valuation process to capture the interlinkages between nature, people and quality of life (Choi \& Fielding 2016; Gould et al. 2015; Raymond \& Kenter 2016; Pascua et al. 2017).

This paradigm shift towards inclusive valuation, currently being advanced by the International Panel on Biodiversity and Ecosystem Services (Pascual et al. 2017), presents a rich opportunity for valuation research. Broadening the theoretical framework within which values are measured; however, it is not without serious challenges (Jacobs et al. 2016). The use of diverse concepts of value does not allow the straightforward aggregation of values across ecosystem services or the comparison of values across ecosystem services and other goods and services in an economy. This may leave decision-makers in the unenviable position of having a lot of information on the value of ecosystem services, but in need of decision tools to use them in order to inform trade-off decisions. This leads to Insight 3 .

Insight 3: co-develop knowledge and decision-support tools with stakeholders and decision-makers throughout the entire ESV process. The aim of ESV is to inform decisions (Daily et al. 2009). The influence of ESV is often conceptual (i.e., knowledge broadens understanding and shapes values), rather than strategic (i.e., supporting specific policy or justifying beliefs/values) or instrumental (i.e., direct use in setting policy) (McKenzie et al. 2014; Ruckelshaus et al. 2015; Waite et al. 2015). Conceptual use of knowledge from ESV is likely to happen early in planning processes, while strategic and instrumental uses often happen later (McKenzie et al. 2014). As such, the whole ESV process should engage people in early phases to broaden and deepen understanding and build shared values, which can foster instrumental use later. This notion is underscored by analyses of the enabling conditions for the practical use of ESV in decision-making, which all point to the need for broad participation (Ruckelshaus et al. 2015; Waite et al. 2015). The three cases illustrate the payoffs of engaging with local stakeholders, decisionmakers and ecological knowledge holders in the ESV process. In Bonaire, for instance, early engagement helped clearly define the policy question at hand and the ecosystem goods and services demanded, their value to society and the most appropriate way to value them.

Specifically to facilitate uptake of ESV into decision-making in islands, van Beukering et al. (2007) created a toolkit calling for intensive stakeholder engagement in all phases: assessing values; scenario analysis/impact assessment and valuation; and decision support. Decision support includes creating tools that synthesize findings (e.g., cost-benefit analysis, multicriteria analysis, etc.) and devising communication strategies to effectively inform decisions. Particular attention needs to be paid to developing decision-support tools in order to overcome the challenges of weighing incommensurate values in decisions (Keeney \& Raiffa 1993; Martín-López et al. 2014).

A key barrier in integrating science into policy are 'black box' analyses that decision-makers cannot defend and do not trust - by engaging decision-makers in the ESV process (and any related modelling), they will have the capacity to explain results, justify assumptions and handle uncertainty. Moreover, collectively grappling with decision-support tools can help decision-makers and stakeholders objectively engage with and understand trade-offs of alternative choices, potentially identifying new options, minimizing conflict and increasing equity. Finally, involving local decision-makers throughout the ESV process can increase institutional capacity to employ systems thinking and ESV in management more generally.

\section{CONCLUSION}

Islands offer an opportunity to investigate ESV within bounded SESs. Lessons learned in islands systems are likely applicable to a wide range of systems. This paper used islands to investigate the evolution of ESV towards a multi-value, participatory, systems paradigm. We saw evidence of this shift in island-based ESVs, though continued methodological development is needed to fully capture the diversity of values and link them to the dynamic social-ecological processes necessary for their production. While ESV has slowly and sporadically transitioned to being more stakeholder driven, interdisciplinary and inclusive - and thus more defensible as policy guidance - to accelerate the trend, decision-makers need to be convinced that the added effort required for integrated valuation is warranted. This calls for valuation researchers to demonstrate the impact of their work (i.e., conceptual, strategic and instrumental use). Examining three cases, we documented how ESV has been used to guide island-scale management and sustainability efforts. The cases revealed a range of uses, from policy-setting to broad sustainability indicators. We noted that the new paradigm can be powerful, but assimilation of ESV into decisions requires strong collaboration between researchers, stakeholders and decision-makers throughout the valuation process, as well as decision-support tools to illustrate trade-offs.

\section{ACKNOWLEDGEMENTS}

Many thanks to Tom Oliver for help with the figures and to three anonymous reviewers whose comments improved the manuscript.

\section{FINANCIAL SUPPORT}

This research received no specific grant from any funding agency, commercial or not-for-profit sectors. 


\section{CONFLICT OF INTEREST}

None.

\section{ETHICAL STANDARDS}

None.

\section{Supplementary material}

To view supplementary material for this article, please visit https://doi.org/10.1017/S0376892918000140

\section{REFERENCES}

Alberti, M., Asbjornsen, H., Baker, L. A., Brozovic, N., Drinkwater, L. E., Drzyzga, S. A., Jantz, C. A., Fragoso, J., Holland, D. S. \& Kohler, T. T. A. (2011) Research on coupled human and natural systems (CHANS): approach, challenges, and strategies. The Bulletin of the Ecological Society of America 92: 218-228.

Alvarez-Romero, J. G., Pressey, R. L., Ban, N. C., Vance-Borland, K., Willer, C., Klein, C. J. \& Gaines, S. D. (2011) Integrated land-sea conservation planning: the missing links. Annual Reviem of Ecology, Evolution, and Systematics 42: 381-409.

Arrow, K. J., Dasgupta, P., Goulder, L. H., Mumford, K. J. \& Oleson, K. (2012) Sustainability and the measurement of wealth. Environment and Development Economics 17: 317353.

Bagstad, K. J., Semmens, D. J., Waage, S. \& Winthrop, R. (2013) A comparative assessment of decision-support tools for ecosystem services quantification and valuation. Ecosystem Services 5: 27-39.

Bagstad, K., Villa, F., Batker, D., Harrison-Cox, J., Voigt, B. \& Johnson, G. (2014) From theoretical to actual ecosystem services: mapping beneficiaries and spatial flows in ecosystem service assessments. Ecology and Society 19(2): 64.

Bennett, E. M., Peterson, G. D. \& Gordon, L. J. (2009) Understanding relationships among multiple ecosystem services. Ecology Letters 12: 1394-1404.

Berkes, F., Colding, J. \& Folke, C. (2000) Rediscovery of traditional ecological knowledge as adaptive management. Ecological Applications 10: 1251-1262.

Berkes, F. \& Folke, C. (1998) Linking social and ecological systems for resilience and sustainability. In: Linking Social and Ecological Systems: Management Practices and Social Mechanisms for Building Resilience, eds F. Berkes \& C. Folke, pp. 1-26. New York, NY, USA: Cambridge University Press.

Boyd, J. \& Banzhaf, S. (2007) What are ecosystem services? The need for standardized environmental accounting units. Ecological Economics 63: 616-626.

Brander, L. M., Florax, R. J. \& Vermaat, J. E. (2006) The empirics of wetland valuation: a comprehensive summary and a meta-analysis of the literature. Environmental and Resource Economics 33: 223250.

Brander, L. M., van Beukering, P. \& Cesar, H. S. (2007) The recreational value of coral reefs: a meta-analysis. Ecological Economics 63: 209-218.

Brander, L. M., Wagtendonk, A. J., Hussain, S. S., McVittie, A., Verburg, P. H., de Groot, R. S. \& van der Ploeg, S. (2012)
Ecosystem service values for mangroves in Southeast Asia: a meta-analysis and value transfer application. Ecosystem Services 1: 62-69.

Bremer, L. L., Jade, M., Delevaux, S., James, J., Leary, K., Cox, L. J., Kirsten, L. \& Oleson, L. (2015) Opportunities and strategies to incorporate ecosystem services knowledge and decision support tools into planning and decision making in Hawai'i. Environmental Management 55: 884.

Brown, C. J., Jupiter, S. D., Albert, S., Klein, C. J., Mangubhai, S., Maina, J. M., Mumby, P., Olley, J., Stewart-Koster, B. \& Tulloch, V. (2017) Tracing the influence of land-use change on water quality and coral reefs using a Bayesian model. Scientific Reports 7: 4740.

Burkhard, B., Kroll, F., Nedkov, S. \& Müller, F. (2012) Mapping ecosystem service supply, demand and budgets. Ecological Indicators 21: 17-29.

Cardno (2016) An assessment of the costs and benefits of mining deep-sea minerals in the Pacific Island region. Suva, Fiji: Pacific Community [www document]. URL http://dsm. gsd.spc.int/images/pdf_files/PIR_CBA_Report.pdf

Carpenter, S. R., Mooney, H. A., Agard, J., Capistrano, D., Defries, R. S., Díaz, S., Dietz, T., Duraiappah, A. K., Oteng-Yeboah, A. \& Pereira, H. M. (2009) Science for managing ecosystem services: beyond the Millennium Ecosystem Assessment. Proceedings of the National Academy of Sciences of the United States of America 106: $1305-1312$.

CBS (2015) Incoming tourism contributed 16.4 percent to Bonaire's economy in 2012 [www document]. URL https://www. cbs.nl/en-gb/news/2015/24/incoming-tourism-contributed16-4-percent-to-bonaire-s-economy-in-2012

Cesar, H. S. \& van Beukering, P. (2004) Economic valuation of the coral reefs of Hawai'i. Pacific Science 58: 231-242.

Chan, K. M., Balvanera, P., Benessaiah, K., Chapman, M., Díaz, S., Gómez-Baggethun, E., Gould, R., Hannahs, N., Jax, K., Klain, S. et al. (2016) Opinion: why protect nature? Rethinking values and the environment. Proceedings of the National Academy of Sciences of the United States of America 113: 1462-1465.

Chan, K. M., Guerry, A. D., Balvanera, P., Klain, S., Satterfield, T., Basurto, X., Bostrom, A., Chuenpagdee, R., Gould, R., Halpern, B. S. et al. (2012a) Where are cultural and social in ecosystem services? A framework for constructive engagement. Bioscience 62 : 744-756.

Chan, K. M., Satterfield, T. \& Goldstein, J. (2012b) Rethinking ecosystem services to better address and navigate cultural values. Ecological Economics 74: 8-18.

Chertow, M., Fugate, E. \& Ashton, W. (2013) The intimacy of human-nature interactions on islands. In: Long Term SocioEcological Research, eds S. J. Singh, H. Haberl, M. Chertow, M. Mirtl \& M. Schmid, p. 590. Dordrecht, The Netherlands: Springer.

Choi, A. S. \& Fielding, K. S. (2016) Cultural attitudes as WTP determinants: a revised cultural worldview scale. Sustainability 8 : 570.

Costanza, R., de Groot, R., Braat, L., Kubiszewski, I., Fioramonti, L., Sutton, P., Farber, S. \& Grasso, M. (2017) Twenty years of ecosystem services: how far have we come and how far do we still need to go? Ecosystem Services 28: 1-16.

Daily, G. (1997) Nature's Services: Societal Dependence on Natural Ecosystems. Washington, DC, USA: Island Press.

Daily, G. C., Polasky, S., Goldstein, J., Kareiva, P. M., Mooney, H. A., Pejchar, L., Ricketts, T. H., Salzman, J. \& Shallenberger, 
R. (2009) Ecosystem services in decision making: time to deliver. Frontiers in Ecology and the Environment 7: 21-28.

Davenport, J. \& Davenport, J. L. (2006) The impact of tourism and personal leisure transport on coastal environments: a review. Estuarine, Coastal and Shelf Science 67: 280-292.

David, G., Herrenschmidt, J. B., Mirault, E. \& Thomassin, A. (2007) Valeur sociale et économique des récifs coralliens du Pacifique insulaire. Projet $1 A 4$ du programme CRISP [www document]. URL http://www.icriforum.org/sites/default/files/GM_DC_MR_ CRISP.pdf

de Groot, R. S., Wilson, M. A. \& Boumans, R. M. (2002) A typology for the classification, description and valuation of ecosystem functions, goods and services. Ecological Economics 41: 393-408.

De Meyer, K. \& MacRae, D. (2006) Bonaire National Marine Park Management Plan [www document]. URL http://www. dcnanature.org/wp-content/uploads/2012/08/ BonaireNationalMarinePark2006ManagementPlan.pdf

Defries, R. S., Foley, J. A. \& Asner, G. P. (2004) Land-use choices: balancing human needs and ecosystem function. Frontiers in Ecology and the Environment 2: 249-257.

Díaz, S., Demissew, S., Carabias, J., Joly, C., Lonsdale, M., Ash, N., Larigauderie, A., Adhikari, J. R., Arico, S. \& Báldi, A. (2015) The IPBES conceptual framework - connecting nature and people. Current Opinion in Environmental Sustainability 14: 1-16.

Dixon, J. A. (2008) Environmental valuation: challenge and practices. Economics and conservation in the tropics: a strategic dialogue. Presented at: Economics and Conservation in the Tropics, San Francisco, CA, USA, 31 January-1 February 2008.

Dixon, J. A., Scura, L. F. \& van't Hof, T. (1993) Meeting ecological and economic goals: the case of marine parks in the Caribbean. Ambio 22: 117-125.

Dixon, J. A., Scura, L. F. \& van't Hof, T. (2000) An economic and ecological analysis of the Bonaire Marine Park. In: Collected Essays on the Economics of Coral Reefs, ed. C. Herman, pp. 158-165. Mombasa, Kenya: Coastal Oceans Research and Development in the Indian Ocean (CORDIO).

EPA (2009) Valuing the Protection of Ecological Systems and Services. Washington, DC, USA: United States Environmental Protection Agency.

Fiji (2007) Fiji National Biodiversity Strategy and Action Plan [www document] URL https://www.cbd.int/doc/world/ fj/fj-nbsap-01-en.pdf

Fiji Bureau of Statistics (2017) Fiji's Gross Domestic Product (GDP) 2016. Suva, Fiji: Government of Fiji.

Fiji DOE (2017) Expansion of Large Scale Marine Managed Areas in Fiji. Suva, Fiji: Government of Fiji.

Fish, R., Church, A. \& Winter, M. (2016) Conceptualising cultural ecosystem services: a novel framework for research and critical engagement. Ecosystem Services 21: 208-217.

Folke, C. (2006) Resilience: the emergence of a perspective for socialecological systems analyses. Global Environmental Change 16: 253 267.

Goldstein, J. H., Caldarone, G., Duarte, T. K., Ennaanay, D., Hannahs, N., Mendoza, G., Polasky, S., Wolny, S. \& Daily, G. C. (2012) Integrating ecosystem-service tradeoffs into landuse decisions. Proceedings of the National Academy of Sciences of the United States of America 109: 7565-7570.

Gonzales, R., Ram-Bidesi, V., Leport, G., Pascal, N., Brander, L., Fernandes, L., Salcone, J. \& Seidl, A. (2015) National Marine Ecosystem Service Valuation Summary Report: Fiji. Suva, Fiji: MACBIO.
Gough, K. V., Bayliss-Smith, T., Connell, J. \& Mertz, O. (2010) Small island sustainability in the Pacific: introduction to the special issue. Singapore Fournal of Tropical Geography 31: 1-9.

Gould, R. K., Klain, S. C., Ardoin, N. M., Satterfield, T., Woodside, U., Hannahs, N., Daily, G. C. \& Chan, K. M. (2015) A protocol for eliciting nonmaterial values through a cultural ecosystem services frame. Conservation Biology 29: 575-586.

Gunderson, L. H. (2001) Panarchy: Understanding Transformations in Human and Natural Systems. Washington, DC, USA: Island Press.

Hau'ofa, E. (1994) Our sea of islands. The Contemporary Pacific 6: $148-161$.

Hawai'i Fresh Water Initiative (2016) A Blueprint for Action: Water Security for an Uncertain Future. Honolulu, HI, USA: Hawai'i Community Foundation.

Helfenstein, J. \& Kienast, F. (2014) Ecosystem service state and trends at the regional to national level: a rapid assessment. Ecological Indicators 36: 11-18.

Hernández-Delgado, E. A. (2015) The emerging threats of climate change on tropical coastal ecosystem services, public health, local economies and livelihood sustainability of small islands: cumulative impacts and synergies. Marine Pollution Bulletin 101: $5-28$.

Hicks, C. C., Levine, A., Agrawal, A., Basurto, X., Breslow, S. J., Carothers, C., Charnley, S., Coulthard, S., Dolsak, N. \& Donatuto, J. (2016) Engage key social concepts for sustainability. Science 352: 38-40.

Hong, S.-K. (2013) Biocultural diversity conservation for island and islanders: necessity, goal and activity. Fournal of Marine and Island Cultures 2: 102-106.

Hussain, S., McVittie, A., Brander, L., Vardakoulias, O., Wagtendonk, A. J., Verburg, P.H., Tinch, R., Fofana, A., Baulcomb, C., Mathieu, L., Ozdemiroglu, E. \& Phang, Z. (2011) The Economics of Ecosystems and Biodiverity Quantitative Assessment. Final report to UNEP. Geneva, Switzerland: UNEP.

IUCN (2016) Protecting the most important marine areas of Fiji [www document]. URL https://www.iucn.org/news/ oceania/201607/protecting-most-important-marine-areas-fiji

Jacobs, S., Dendoncker, N., Martín-López, B., Barton, D. N., Gomez-Baggethun, E., Boeraeve, F., McGrath, F. L., Vierikko, K., Geneletti, D. \& Sevecke, K. J. (2016) A new valuation school: integrating diverse values of nature in resource and land use decisions. Ecosystem Services 22: 213-220.

Keeney, R. L. \& Raiffa, H. (1993) Decisions with Multiple Objectives: Preferences and Value Trade-Offs. Cambridge, UK: Cambridge University Press.

Kenter, J. O., Jobstvogt, N., Watson, V., Irvine, K. N., Christie, M. \& Bryce, R. (2016) The impact of information, valuedeliberation and group-based decision-making on values for ecosystem services: integrating deliberative monetary valuation and storytelling. Ecosystem Services 21: 270-290.

Kenter, J. O., O'Brien, L., Hockley, N., Ravenscroft, N., Fazey, I., Irvine, K. N., Reed, M. S., Christie, M., Brady, E. \& Bryce, R. (2015) What are shared and social values of ecosystems? Ecological Economics 111: 86-99.

Klein, C. J., Jupiter, S. D., Watts, M. \& Possingham, H. P. (2014) Evaluating the influence of candidate terrestrial protected areas on coral reef condition in Fiji. Marine Policy 44: 360-365.

Koks, E., van Zanten, B. T. \& Wolfs, E. (2015) User Manual GEM Tool. Amsterdam, The Netherlands: Institute for Environmental Studies, Vrije Universiteit Amsterdam. 
Kremen, C. (2005) Managing ecosystem services: what do we need to know about their ecology? Ecology Letters 8: 468-479.

Kushner, B., Jungwiwattanaporn, M., Waite, R. \& Burke, L. (2012) Influence of coastal economic valuations in the Caribbean: enabling conditions and lessons learned [www document]. URL http://bibliotecavirtual.minam.gob.pe/biam/handle/minam/ 1797

Lal, P. (2004) Coral reef use and management - the need, role, and prospects of economic valuation in the Pacific. In: Economic Valuation and Policy Priorities for Sustainable Management of Coral Reefs, pp. 59-78. Penang, Malaysia: WorldFish.

Laurans, Y., Pascal, N., Binet, T., Brander, L., Clua, E., David, G., Rojat, D. \& Seidl, A. (2013a) Economic valuation of ecosystem services from coral reefs in the South Pacific: taking stock of recent experience. Fournal of Environmental Management 116: 135144.

Laurans, Y., Rankovic, A., Billé, R., Pirard, R. \& Mermet, L. (2013b) Use of ecosystem services economic valuation for decision making: questioning a literature blindspot. Fournal of environmental management 119: 208-219.

Lawn, P. A. (2003) A theoretical foundation to support the index of sustainable economic welfare (ISEW), genuine progress indicator (GPI), and other related indexes. Ecological Economics 44: 105-118.

Liu, J., Dietz, T., Carpenter, S. R., Alberti, M., Folke, C., Moran, E., Pell, A. N., Deadman, P., Kratz, T., Lubchenco, J. et al. (2007) Complexity of coupled human and natural systems. Science 317: 1513-1516.

Macarthur, R. H. \& Wilson, E. O. (1967) The Theory of Island Biogeography. Princeton, NJ, USA: Princeton University Press.

Mangubhai, S. (2017) Fiji Makes 17 Major Commitments to the Ocean. WCS United Nations Ocean Conference Blog [www document]. URL https://medium.com/wcs-marineconservation-program/fiji-makes-16-major-commitments-tothe-ocean-c6f8efce02cd

Marre, J.-B., Thébaud, O., Pascoe, S., Jennings, S., Boncoeur, J. \& Coglan, L. (2016) Is economic valuation of ecosystem services useful to decision-makers? Lessons learned from Australian coastal and marine management. Fournal of Environmental Management 178: 52-62.

Martin, E. A. H. K. P., Martin, D. L., Penn, D. C. \& McCarty, J. E. (1996) Cultures in conflict of Hawai'i: The law and politics of native Hawaiian water rights. University of Hawai'i Lam Reviem 18: 71 .

Martín-López, B., Gómez-Baggethun, E., García-Llorente, M. \& Montes, C. (2014) Trade-offs across value-domains in ecosystem services assessment. Ecological Indicators 37: 220 228.

Mavrommati, G., Borsuk, M. \& Howarth, R. (2017) A novel deliberative multicriteria evaluation approach to ecosystem service valuation. Ecology and Society 22(2): 39.

McFarland, K. \& Gerdes, H. (2016) Uptake of Ecosystem Valuations in Policymaking in Europe's Overseas Entities: Application, Barriers to Use, and Opportunities for Improved Uptake. Grant Agreement No. 603710. Berlin, Germany: Ecologic Institute.

McKenzie, E., Posner, S., Tillmann, P., Bernhardt, J. R., Howard, K. \& Rosenthal, A. (2014) Understanding the use of ecosystem service knowledge in decision making: lessons from international experiences of spatial planning. Environment and Planning C: Government and Policy 32: 320-340.

Millennium Ecosystem Assessment (2005) Ecosystems and Human Well-Being. Washington, DC, USA: Island Press.
Mumby, P., Flower, J., Chollett, I., Box, S., Bozec, Y., Fitzsimmons, C., Forster, J., Gill, D., Griffith-Mumby, R. \& Oxenford, H. A. (2014) Tomards Reef Resilience and Sustainable Livelihoods: A Handbook for Caribbean Coral Reef Managers. Devon, UK: University of Exeter.

Narayan, S., Beck, M. W., Wilson, P., Thomas, C. J., Guerrero, A., Shepard, C. C., Reguero, B. G., Franco, G., Ingram, J. C. \& Trespalacios, D. (2017) The value of coastal wetlands for flood damage reduction in the northeastern USA. Scientific Reports 7: 9463.

Nelson, E., Mendoza, G., Regetz, J., Polasky, S., Tallis, H., Cameron, D. R., Chan, K., Daily, G. C., Goldstein, J., Kareiva, P. M. et al. (2009) Modeling multiple ecosystem services, biodiversity conservation, commodity production, and tradeoffs at landscape scales. Frontiers in Ecology and the Environment 7: 4-11.

Nelson, G. C., Dobermann, A., Nakicenovic, N. \& O’Neill, B. C. (2006) Anthropogenic drivers of ecosystem change: an overview. Ecology and Society 11(2): 29.

Norton, B., Costanza, R. \& Bishop, R. C. (1998) The evolution of preferences: why 'sovereign' preferences may not lead to sustainable policies and what to do about it. Ecological Economics 24: 193-211.

Nunes, P. A. (2014) Guidance Manual on Valuation and Accounting of Ecosystem Services for Small Island Developing States. Nairobi, Kenya: UNEP, Ecosystem Services Economics Unit, Division of Environmental Policy Implementation.

O'Garra, T. (2012) Economic valuation of a traditional fishing ground on the coral coast in Fiji. Ocean E Coastal Management 56: 44 55 .

Openbaar Lichaam Bonaire (2015) Draft Integrated Multi-Year Plan Bonaire 2015-2025. Kralendijk, Bonaire: Openbaar Lichaam Bonaire.

Ostergaard-Klem, R. \& Oleson, K. L. (2014) GPI island style: Localizing the genuine progress indicator to Hawaii. Environmental Practice 16: 182-193.

Pachauri, R. K. \& Reisinger, A. (2007) Climate Change 2007: Synthesis Report. Geneva, Switzerland: IPCC.

Parsons, G. R. \& Thur, S. M. (2008) Valuing changes in the quality of coral reef ecosystems: a stated preference study of SCUBA diving in the Bonaire National Marine Park. Environmental and Resource Economics 40: 593-608.

Pascal, N., Brander, L., Clua, E., Gilbert, D., Yann, L. \& Seidl, A. (2012) What impacts to expect from economic valuation of coral reefs. Presented at: Proceedings of the 12th International Coral Reef Symposium, Cairns, Australia.

Pascal, N. \& Seidl, A. (2013) Economic Benefits of Marine Protected Areas: Case Studies in Vanuatu and Fiji, South Pacific. IUCN and $A F D$. Gland, Switzerland: IUCN.

Pascua, P., McMillen, H., Ticktin, T., Vaughan, M. \& Winter, K. B. (2017) Beyond services: a process and framework to incorporate cultural, genealogical, place-based, and indigenous relationships in ecosystem service assessments. Ecosystem Services 26(B): 465475.

Pascual, U., Balvanera, P., Díaz, S., Pataki, G., Roth, E., Stenseke, M., Watson, R. T., Dessane, E. B., Islar, M. \& Kelemen, E. (2017) Valuing nature's contributions to people: the IPBES approach. Current Opinion in Environmental Sustainability 26: 7-16.

Pascual, U., Muradian, R., Brander, L., Gómez-Baggethun, E., Martín-López, B., Verma, M., Armsworth, P., Christie, M., Cornelissen, H., Eppink, F. et al. (2010) The Economics of Valuing 
Ecosystem Services and Biodiversity. Geneva, Switzerland: TEEB - Ecological and Economic Foundation.

Pleasant, M. M., Gray, S. A., Lepczyk, C., Fernandes, A., Hunter, N. \& Ford, D. (2014) Managing cultural ecosystem services. Ecosystem Services 8: 141-147.

Rao, N., Carruthers, T. J., Anderson, P., Sivo, L., Saxby, T., Durbin, T., Jungblut, V., Hills, T. \& Chape, S. (2013) An Economic Analysis of Ecosystem-based Adaptation and Engineering Options for Climate Change Adaptation. Apia, Samoa: Secretariat of the Pacific Regional Environment Programme.

Raymond, C. M. \& Kenter, J. O. (2016) Transcendental values and the valuation and management of ecosystem services. Ecosystem Services 21: 241-257.

Reuter, K. E., Juhn, D. \& Grantham, H. S. (2016) Integrated landsea management: recommendations for planning, implementation and management. Environmental Conservation 43: 181-198.

Ruckelshaus, M., Klinger, T., Knowlton, N. \& DeMaster, D. P. (2008) Marine ecosystem-based management in practice: scientific and governance challenges. AIBS Bulletin 58: 53-63.

Ruckelshaus, M., McKenzie, E., Tallis, H., Guerry, A., Daily, G., Kareiva, P., Polasky, S., Ricketts, T., Bhagabati, N., Wood, S. A. et al. (2015) Notes from the field: lessons learned from using ecosystem service approaches to inform real-world decisions. Ecological Economics 115: 11-21.

Russell, R., Guerry, A. D., Balvanera, P., Gould, R. K., Basurto, X., Chan, K. M., Klain, S., Levine, J. \& Tam, J. (2013) Humans and nature: how knowing and experiencing nature affect well-being. Annual Reviem of Environment and Resources 38: 473-502.

Salcone, J., Brander, L. \& Seidl, A. (2016) Guidance Manual on Economic Valuation of Marine and Coastal Ecosystem Services in the Pacific. Report to the MACBIO Project (GIZ, IUCN, SPREP). Suva, Fiji: MACBIO.

Satz, D., Gould, R. K., Chan, K. M., Guerry, A., Norton, B., Satterfield, T., Halpern, B. S., Levine, J., Woodside, U., Hannahs, N. et al. (2013) The challenges of incorporating cultural ecosystem services into environmental assessment. Ambio 42: 675.

Schep, S., Brander, L., van Beukering, P. \& Wolfs, E. (2012) The Touristic Value of Nature on Bonaire. A Multiple Valuation Techniques Approach. Report Number R13-02. Amsterdam, The Netherlands: Institute for Environmental Studies, Vrije Universiteit Amsterdam.

Secretariat of the Pacific Community (2017a) International Merchandise Trade Statistics. PRISM: Pacific Community [www document]. URL https://prism.spc.int/regional-dataand-tools/economic-statistics

Secretariat of the Pacific Community (2017b) National Minimum Development Indicators Version 2.0 household indicators (agriculture \& forestry) [www document]. URL http://www. spc.int/nmdi/agriculture_households

Seppelt, R., Dormann, C. F., Eppink, F. V., Lautenbach, S. \& Schmidt, S. (2011) A quantitative review of ecosystem service studies: approaches, shortcomings and the road ahead. Fournal of Applied Ecology 48: 630-636.

Sewell, A. (2015) Show me the money. Developing solutions towards sustainable financing of the Bonaire National Marine Park. Master thesis, Institute for Environmental Studies, Vrije Universiteit Amsterdam, The Netherlands.

Sisto, N. P. (1999) An economic valuation of Fiji's major natural ecosystems. Fournal of Pacific Studies 23: 71-90.

Spergel, B. (2005) Sustainable Funding for Nature Parks in The Netherlands Antilles. Feasibility Study of a Protected Areas Trust
Fund SYNOPSIS. Aidenvironment (Amsterdam), Ecovision (Curaçao). Kralendijk, Bonaire: DCBD.

State of Hawai'i (2008) H.B.3176. Relating to Administrative Penalties for Damage to Stony Coral and Live Rock. A Bill for an Act. House of Representatives, Twenty-Fourth Legislature. Honolulu, HI, USA: State of Hawai'i.

State of Hawai'i DBEDT (2016) Data Book [www document]. URL http://dbedt.hawaii.gov/economic/databook/db2016/

State of Hawai'i DBEDT (2017) Outlook for the Economy [www document]. URL http://dbedt.hawaii.gov/economic/ qser/outlook-economy/

State of Hawai'i DLNR (2010) Issue 8: Forest Products and Carbon Sequestration [www document]. URL http://dlnr. hawaii.gov/forestry/files/2013/09/SWARS-Issue-8.pdf

State of Hawai'i DLNR (2011) The Rain Follows the Forest: Hahai no ka ua $i$ ka ululā'au. Honolulu, HI, USA: State of Hawai'i.

Statline (2017) Caribbean Netherlands gross domestic product [www document]. URL https://opendata.cbs.nl/ statline/\#/CBS/en/dataset/83776ENG/table?dl=399C

STINAPA (2008) National Parks Foundation [www document]. URL www.stinapa.org

Stoms, D. M., Davis, F. W., Andelman, S. J., Carr, M. H., Gaines, S. D., Halpern, B. S., Hoenicke, R., Leibowitz, S. G., Leydecker, A., Madin, E. M. et al. (2005) Integrated coastal reserve planning: making the land-sea connection. Frontiers in Ecology and the Environment 3: 429-436.

Tabunakawai-Vakalalabure, M., Bertram, I., James, P. A. S., Lalavanua, W. \& Mangubhai, S. (2017) UBA: What Is the Social and Economic Cost to Society. Fiji's Sea Cucumber Fishery: Advances in Science for Improved Management. Wildlife Conservation Society. Report, pp. 47-53. Suva, Fiji: Wildlife Conservation Society.

Thur, S. M. (2010) User fees as sustainable financing mechanisms for marine protected areas: an application to the Bonaire National Marine Park. Marine Policy 34: 63-69.

United Nations Development Programme (2012) Fiji LocallyManaged Marine Area Network, Fiji. New York, NY, USA: UNDP.

UNU-IHDP (2012) Inclusive Wealth Report 2012: Measuring Progress tomard Sustainability. New York, NY, USA: Cambridge University Press.

van Berkel, D. B. \& Verburg, P. H. (2014) Spatial quantification and valuation of cultural ecosystem services in an agricultural landscape. Ecological Indicators 37: 163-174.

van Beukering, P., Brander, L., Tompkins, E. \& McKenzie, E. (2007) Valuing the Environment in Small Islands - An Environmental Economics Toolkit. Peterborough, UK: Joint Nature Conservation Committee.

van Beukering, P. \& Cesar, H. S. (2004) Ecological economic modeling of coral reefs: evaluating tourist overuse at Hanauma Bay and algae blooms at the Kihei Coast, Hawai'i. Pacific Science 58: 243-260.

van Beukering, P. \& Lea, M. (2013) The role of marine protected areas in alleviating poverty in the Asia Pacific. In: Nature's Wealth: The Economics of Ecosystem Services and Poverty, p. 115. New York, NY, USA: Cambridge University Press.

Villamagna, A. M., Angermeier, P. L. \& Bennett, E. M. (2013) Capacity, pressure, demand, and flow: a conceptual framework for analyzing ecosystem service provision and delivery. Ecological Complexity 15: 114-121. 
Wada, C. A., Bremer, L. L., Burnett, K., Trauernicht, C., Giambelluca, T., Mandle, L., Parsons, E., Weil, C., Kurashima, N. \& Ticktin, T. (2017) Estimating cost-effectiveness of Hawaiian dry forest restoration using spatial changes in water yield and landscape flammability under climate change. Pacific Science 71: 401-424

Waite, R., Kushner, B., Jungwiwattanaporn, M., Gray, E. \& Burke, L. (2015) Use of coastal economic valuation in decision making in the Caribbean: enabling conditions and lessons learned. Ecosystem Services 11: 45-55.

Walker, B., Holling, C. S., Carpenter, S. \& Kinzig, A. (2004) Resilience, adaptability and transformability in social-ecological systems. Ecology and Society 9: 5.
Wilson, M. A. \& Howarth, R. B. (2002) Discourse-based valuation of ecosystem services: establishing fair outcomes through group deliberation. Ecological Economics 41: 431-443.

World Travel \& Tourism Council (2015) Travel \& Tourism Economic Impact 2015 Fiji. London, UK: WTTC.

Yee, S. H., Carriger, J. F., Bradley, P., Fisher, W. S. \& Dyson, B. (2015) Developing scientific information to support decisions for sustainable coral reef ecosystem services. Ecological Economics 115: $39-50$.

Yee, S. H., Dittmar, J. A. \& Oliver, L. M. (2014) Comparison of methods for quantifying reef ecosystem services: a case study mapping services for St. Croix, USVI. Ecosystem Services 8: $1-15$. 